\title{
Yield, milk quality and physiological variables of dairy cows in rainy and dry seasons
}

\section{Produção, qualidade do leite e variáveis fisiológicas de vacas leiteiras em pastejo rotacionado na estação seca e chuvosa}

\author{
Evaldo de Almeida Cardoso'; Dermeval Araujo Furtado2; Neila Lidiany Ribeiro3*; \\ Ariosvaldo Nunes de Medeiros"; George Vieira do Nascimento3; Severino Gonzaga \\ Neto ${ }^{5}$; José Wallace Barbosa do Nascimento ${ }^{2}$; Rogério Aleson Dias Bezerra ${ }^{7}$
}

\section{Highlights}

Temperatura superficial foi maior na estação seca.

Frequência respiratória foi maior na estação seca.

Teor de proteina do leite foi maior na estação seca.

Gordura e lactose mantiveram-se na estação seca e chuvosa.

\begin{abstract}
The objective of this study was to analyse the effect of the dry and rainy seasons on the production, milk quality (lactose, fat, protein, total solids, TBC and SCC) and physiological (rectal and surface temperature and respiratory and heart rate) of crossbred cows (holstein/ zebu) in lactation, under rotational grazing regime in cultivated pasture, using 10 crossbred cows (holstein / zebu) in lactation, average live weight of $500 \pm 30 \mathrm{~kg}$, and in the rainy season they were between the fourth and fifth months of lactation and in the dry period were between the seventh and eighth months of lactation with an average initial production of $18 \pm 4 \mathrm{~kg}$ of milk / cow / day, maintaining batch homogeneity in both seasons. The animals were kept in a semi-intensive rearing system, using rotational grazing on pasture of Brachiaria decumbens, in an area of 3 hectares, where there was a conglomerate of trees that provided $5 \mathrm{~m}^{2} /$ animal with natural shade, to shelter the animals in the warm shorelines The seasons and times of the day significantly influenced $(P<0.05)$ the ambient temperature,

1 Zootechnician at the Center for Agricultural Sciences, Federal University of Paraíba, UFPB, Areia, PB, Brazil. E-mail: evaldo@cca.ufpb.br

2 Profs. Titular, Agricultural Engineering Academic Unit, Federal University of Campina Grande, UFCG, Campina Grande, PB, Brazil. E-mail: araujodermeval@gmail.com; wallacebosa@hotmail.com

${ }^{3}$ Researchers, National Institute of Semi-Arid, Campina Grande, PB, Brazil. E-mail: neilalr@hotmail.com; george.vieira@ insa.gov.br

${ }^{4}$ Prof. Titular, Agricultural Sciences Center, UFPB, Areia, PB, Brazil. E-mail: ariosvaldo.medeiros@gmail.com

5 Prof. Associate, Agricultural Sciences Center, UFPB, Areia, PB, Brazil. E-mail: sgonzaganeto@gmail.com

${ }^{6} \mathrm{PhD}$ Student in Animal Science, Postgraduate Program in Animal Science, State University of Maringá, UEM, Maringá, PR, Brazil. E-mail: rogerioaleson@hotmail.com

* Author for correspondence
\end{abstract}

Received: Mar 30, 2020 - Approved: Nov. 24, 2020 
relative air humidity and the black globe temperature index and humidity. The respiratory rate and surface temperature were higher $(P<0.05)$ in the dry season and the values for rectal temperature and respiratory rate were similar $(P>0.05)$ in the seasons. Milk production and protein showed a significant difference $(P<$ 0.05 ) depending on the seasons. With the aid of physiological variables (rectal and surface temperature and heart and respiratory rate), even so, cows decreased their production and increased the concentration of protein in milk.

Key words: Brachiaria decumbens. Milk protein. Somatic cell count. Total bacterial count.

\section{Resumo}

O objetivo com esta pesquisa foi analisar o efeito das estações seca e chuvosa sobre a produção, qualidade do leite (gordura, lactose, proteína, sólidos totais, CTB e CCS) e as variáveis fisiológicas (temperatura retal e superficial e frequência respiratória e cardíaca) de vacas mestiças (holandês/zebu) em lactação, sob regime de pastejo rotacionado em pastagem cultivada, utilizando-se 10 vacas mestiças (holandês/zebu) em lactação, peso vivo médio de $500 \pm 30 \mathrm{~kg}$, sendo que no período chuvoso estavam entre o quarto e quinto mês de lactação e no período seco estavam entre o sétimo e oitavo mês de lactação com uma produção média inicial de $18 \pm 4 \mathrm{~kg}$ de leite/vaca/dia, mantendo homogeneidade do lote nas duas estações. Os animais foram mantidos em sistema semi-intensivo de criação, utilizando pastejo rotacionado em pastagem de Brachiaria decumbens, numa área de 3 hectares, onde existia um conglomerado de árvores que propiciavam $5 \mathrm{~m}^{2}$ /animal de sombra natural, para abrigar os animais nos horários mais quentes do dia. As estações do ano e os horários do dia influenciaram significativamente $(P<0,05)$ a temperatura do ambiente, umidade relativa do ar e o índice de temperatura de globo negro e umidade. A frequência respiratória e a temperatura superficial foram mais elevadas $(P<0,05)$ na estação seca e os valores da temperatura retal e frequência respiratória foram similares $(P>0,05)$ nas estações. A produção e a proteína do leite apresentaram diferença significativa $(P<0,05)$ em função das estações do ano. Com o auxílio das variáveis fisiológicas (temperatura retal e superficial e frequência cardíaca e respiratória), mesmo assim, as vacas diminuíram sua produção e aumentaram a concentração de proteína no leite.

Palavras-chave: Brachiaria decumbens. Contagem de células somáticas. Contagem bacteriana total. Proteína do leite.

\section{Introduction}

Pastures of tropical forage grasses when properly managed can withstand high stocking rates; one of the systems used rotational grazing, favours the quality and efficiency of forage use and consequently improves animal production (Diehl et al., 2013; Moreira et al., 2015).

Understanding the causes of variation in milk production and composition are important in production systems (Moreira et al., 2015), where seasonal differences in milk production are caused by climate change during the seasons (Bertocchi et al., 2014; Bernabucci et al., 2015). The dry period in tropical and semiarid regions can have a negative effect on milk production, as the production of dry matter in forage decreases and the fibre content of food increases; this can lead to decreases in the supply, consumption and digestibility of nutrients (Ramos et al., 2015) and the need for 
bulky and/or concentrated supplementation (R. C. Souza et al., 2015).

Climatic elements interfere significantly with the behaviour, physiology, production and quality of bovine milk, especially in genetically improved animals (Lima et al., 2013), and physiological variables such as rectal and surface temperature and heart and respiratory rates can change in improved dairy cows raised in warm environments (Pereira, Cunha, Cecon, \& Faria, 2008; Ávila, Jácome, Faccenda, Panazzolom, \& Muller, 2013). The consumption of dry matter and water can also decrease, altering gastrointestinal functioning. This causes a decrease in production and changes in physiological responses, with dairy cattle with a higher genetic composition of European animals, such as the Holstein breed, showing greater sensitivity to heat stress than cows with a higher percentage of zebu genetic makeup (Perissinotto et al., 2009; Lima et al., 2013).

The objective of this research was to investigate the effect of the season on the production, milk quality and physiological variables (rectal and surface temperature and respiratory and heart rate) of lactating crossbred (Holstein/zebu) cows, under rotational grazing on cultivated pasture.

\section{Material and Methods}

\section{Experiment location}

The work was carried out in accordance with the ethical standards for research involving animals, being submitted to the Ethics Committee on the Use of Animals at the Biotechnology Centre of the Federal University of Paraíba (CEUA/BIOTEC/UFPB; 072/2016).
The experiment was carried out in the dairy cattle sector at the Federal University of Paraíba, Areia, PB, located in the mesoregion of Agreste Paraibano and microregion of Brejo Paraibano, located at 6 $6^{\circ} 58^{\prime} 12^{\prime \prime}$ S and $35^{\circ} 45^{\prime} 15^{\prime \prime}$ W Gr, $620 \mathrm{~m}$ above sea level. The climate of the region according to Köppen classification is of the As' type (hot and humid), with autumnwinter rains and a dry period of 5 to 6 months. Data collection was performed in two different seasons, featuring two experimental phases, the rainy season (July/August) and dry season (October/November).

\section{Animals, paddocks and diet}

The study used 10 crossbred cows (holstein/zebu) in lactation with an average live weight of $500 \pm 30 \mathrm{~kg}$. In the rainy season they were between the fourth and fifth months of lactation and in the dry season they were between the seventh and eighth months of lactation. Average production was $18 \pm 4 \mathrm{~kg}$ of milk/cow/day, and batch homogeneity was maintained in both seasons.

The animals were kept in a semiintensive rearing system, using rotational grazing on Brachiaria decumbens pasture, formed by three paddocks each with an average of 2 ha, not counting the area of natural shade. In the grazing area there was a conglomerate of trees (Prosopis juliflora Sw. DC) that provided natural shade, to shelter the animals at the hottest times of the day $(1112.28,2918.28$ and $381.12 \mathrm{~m}^{2}$, respectively, in the three paddocks). There was also an area shaded with eucalyptus (Eucalyptus) in each paddock (938.00, 2464.00 and $1096 \mathrm{~m}^{2}$, respectively) (Figure 1). 


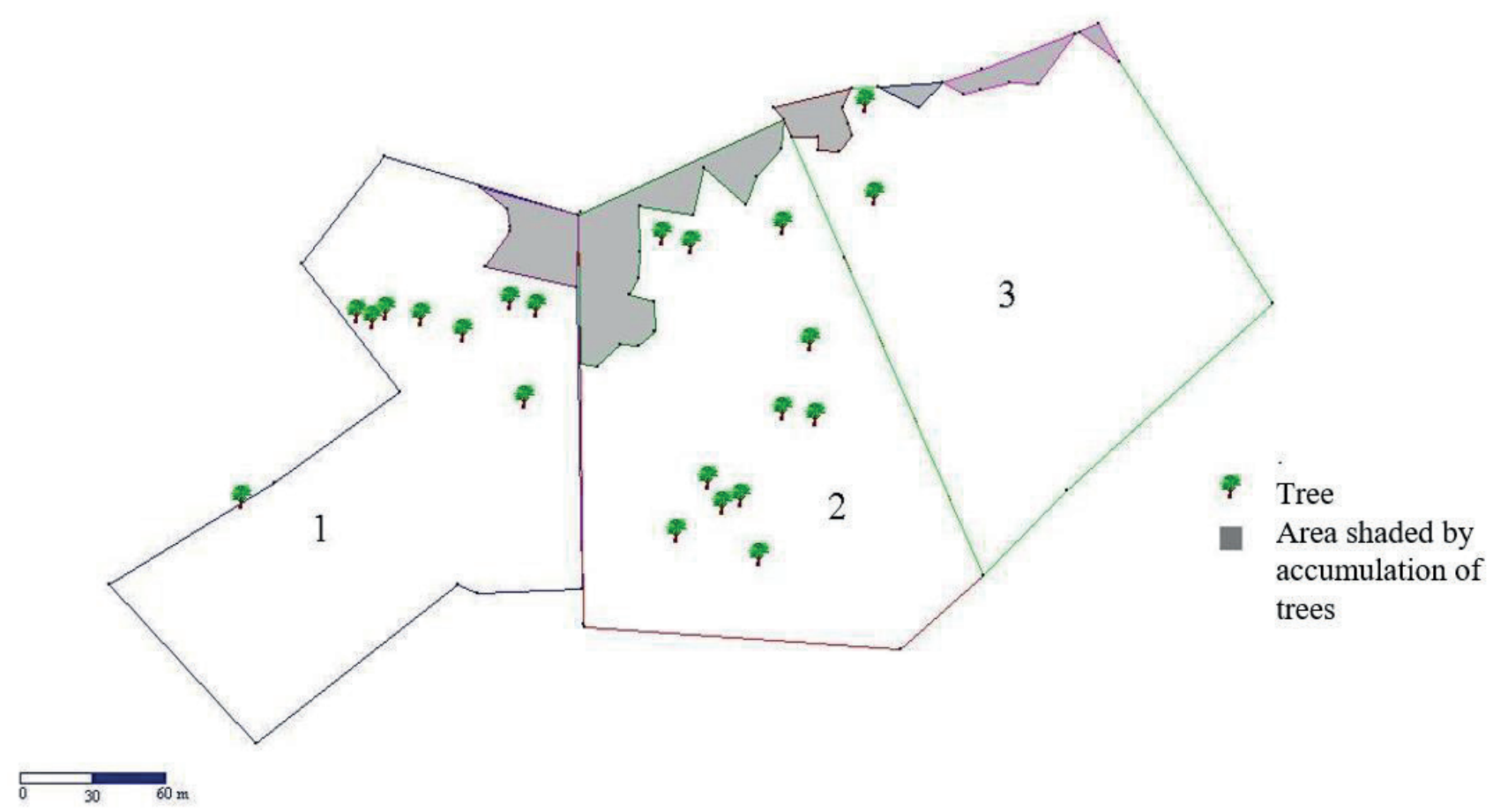

Figure 1. Experiment area.

Concentrate consisting of $20 \%$ soy bean, $20 \%$ cotton bran, $48 \%$ ground whole corn, $8 \%$ wheat bran and $4 \%$ mineral salt was supplied twice a day, in a proportion of $1 \mathrm{~kg}$ of feed for every $4 \mathrm{~L}$ of milk produced per cow, in individual troughs.

\section{Milking}

The cows were milked mechanically twice a day, at $05 \mathrm{~h} 30$ and $13 \mathrm{~h} 00$. The animals were removed from the paddocks at $05 \mathrm{hO0}$ and taken to the waiting pen, where they had free access to mineral salt and water, received their first supplementation (with $21 \%$ crude protein) and remained until milking time. For milking, the teats were washed and then pre-dipped with chlorinated solution; after milking, postdipping was performed with iodized solution and the animals' production was measured individually. After the morning milking the animals were taken back to the paddocks. At $14 \mathrm{hO0}$ the animals were taken to the milking parlour for the second milking. At the end of this, the animals returned to the paddocks where they stayed overnight.

The milk production of the animals was assessed eight times in the two seasons, with four fortnightly evaluations being carried out in each season (dry and rainy).

\section{Milk collection and centesimal analysis}

The milk samples were collected immediately after milking, using sterile materials and aseptic collection procedures, kept under refrigeration and sent to the UFRPE Northeast Herd Management Program (PROGENE) where physical-chemical analysis 
of milk (fat, protein, lactose and total solids), somatic cell count (SCC) and total bacterial count (TBC) were performed.

For these analyses, $40 \mathrm{~mL}$ of milk was collected and identified, then aseptically packed in $50 \mathrm{~mL}$ sterile plastic bottles containing the preservative bronopol. The milk and preservative were homogenized by inversion until completely dissolved and then sent to the laboratory. After being conditioned in identified plastic bottles, the samples were subjected to a slow thermal pasteurization process at $65^{\circ} \mathrm{C}$ for 30 min and finally frozen at $-4{ }^{\circ} \mathrm{C}$ for further analysis (Instrução Normativa $\left.n^{\circ} 37\right)$. The Fat (\%), total solids (\%), proteins (\%) and lactose (\%) were analysed using Master Complete ${ }^{\circledR}$ milk (AKSO ${ }^{\circledR}$, São Leopoldo, Rio Grande do Sul, Brazil), under specific technical conditions. The SCC and TBC analyses were performed on Bentley Combi System 2300R equipment, composed of a Bentley 2000 unit and a Somacount 300 flow cytometry unit.

\section{Physiological variables}

To assess the physiological variables, respiratory rate (RR; $\mathrm{mov} / \mathrm{min})$, rectal temperature $\left(\mathrm{RT} ;{ }^{\circ} \mathrm{C}\right)$, heart rate (HR; beats/ min) and surface temperature $\left(\mathrm{ST} ;{ }^{\circ} \mathrm{C}\right)$ were measured at three different times (from 7h00 to $8 \mathrm{h00}, 12 \mathrm{hO0}$ to $13 \mathrm{hO0}$ and $16 \mathrm{h00}$ to $17: 00$ ) once a week, during both seasons. Averages of the three collections were used to discuss the results.

TR was measured with a clinical thermometer in the range of 32 to $43.9^{\circ} \mathrm{C}$. The thermometer was inserted into the rectum of each animal, with the bulb in contact with the mucosa, and kept in the rectum until the temperature stabilized. The RR and HR were measured by auscultating cardiac sounds with the aid of a flexible stethoscope, at the level of the laryngeal-tracheal region, counting the number of movements and beats for 20 $\mathrm{s}$; the results were multiplied by 3 to express the values on a minute-hour scale. Surface temperature on the left flank was recorded using a digital infrared thermometer (Minibar MT-350, São Paulo, Brazil) at a distance of 10 to $50 \mathrm{~cm}$ from the body (there is no difference in measurements between these distances).

\section{Meteorological variables}

Meteorological variables in the external environment were recorded using a datalogger (HT-500, INSTRUTHERM): dry bulb temperature $\left({ }^{\circ} \mathrm{C}\right)$, black globe temperature $\left({ }^{\circ} \mathrm{C}\right)$, relative air humidity $(\mathrm{RU}, \%)$ and wind speed $(\mathrm{m} / \mathrm{s})$. Readings were taken every 60 min over $24 \mathrm{~h}$. The black globe was fixed in the external environment in the geometric centre of the pasture at $1.0 \mathrm{~m}$ above the ground and protected by an electrified fence. The black globe was measured with the aid of a hollow polyethylene sphere, $15 \mathrm{~cm}$ in diameter, painted in matte black. The globe temperature and humidity index were determined from the meteorological variables recorded using the formulas described by Buffington, ColazzoArocho, Canton and Pitt (1981).

\section{Statistical analysis}

The experimental design adopted was completely randomized (DIC), with a 2 $\times 6$ factorial design for the meteorological data (two stations and six times throughout the day). The physiological variables and milk production and composition were evaluated 
considering a DIC with the effect of the season (dry and rainy), comprising 60 days for each season, with 10 repetitions.

The meteorological data were analysed using PROC GLM in Statistical Analysis System Institute [SAS Institute] (2001), applying the Tukey test at the level of $5 \%$ probability. The SCC and TBC data were transformed into logarithms, at base 10 , to proceed with the analysis. The physiological, productive and chemical data of milk were analysed by bidirectional analysis of variance using PROC MIXED in SAS Institute (2001), considering the fixed effect of season, applying the TukeyKramer test at the level of $5 \%$ probability.

The mathematical model used was as follows:

$$
\mathrm{Y}_{\mathrm{ik}}=\mu+\mathrm{S}_{\mathrm{i}}+\mathrm{E}_{\mathrm{ik}}
$$

where: Yik is the dependent variable, $\mu$ is the general measure, $\mathrm{Si}$ is the fixed effect of the season ( $\mathrm{i}=1$ dry, $\mathrm{i}=2$ rain) and Eik is the experimental error.

\section{Results and Discussion}

The season and time of day significantly influenced $(P<0.05)$ the ambient temperature, UR and BGTHI; the lowest mean AT was recorded from $00 \mathrm{hO0}$ to $03 \mathrm{hOO}$ in the rainy season $\left(19.75^{\circ} \mathrm{C}\right)$ and the highest from $12 \mathrm{hO0}$ to $15 \mathrm{hO0}$ in the dry season $\left(27.74^{\circ} \mathrm{C}\right)$ and, at all times analysed, the TA was higher $(P<0.05)$ in the dry season (Table 1). In the rainy season, there was an average increase of $15 \%$ between the minimum (00h00 to $03 \mathrm{hO0}$ ) and maximum (12h00 to 15h00) ambient temperature and in the dry season there was an increase of approximately $22 \%$ between these hours.

The RU showed minimum values between $8 \mathrm{h00}$ and $19 \mathrm{h00}$ (average of $79.45 \%$ ) in the dry season; at other times they were statistically similar. The BGTHI presented higher averages in the dry season, ranging from 69.77 (from 00h00 to 03h00) to 82.79 (from 12h00 to $15 \mathrm{~h} 00)$, whereas in the rainy season it ranged from 67.54 to 76.49 from $00 \mathrm{h00}$ to $03 \mathrm{hO0}$ and from $12 \mathrm{~h} 00$ to $15 \mathrm{~h} 00$, respectively (Table 1 ).

The means of RT and HR did not show any significant difference $(P>0.05)$ between seasons and ST and RR were higher $(P<0.05)$ in the dry season (Table 2). 
Table 1

Effect of the dry and rainy season and the period of the day on the environmental parameters recorded during the experiment

\begin{tabular}{|c|c|c|c|c|}
\hline Season & Period & Ambient temperature $\left({ }^{\circ} \mathrm{C}\right)$ & $\left({ }^{\circ} \mathrm{C}\right)$ Relative humidity $(\%)$ & BGTHI \\
\hline \multirow{2}{*}{$\begin{array}{c}\text { Rainy } \\
\text { Dry }\end{array}$} & \multirow{2}{*}{ 00h00-03h00 } & $19.75 b$ & $95.72 \mathrm{a}$ & $67.54 \mathrm{~b}$ \\
\hline & & $21.63 a$ & $97.75 a$ & $69.77 \mathrm{a}$ \\
\hline \multirow{2}{*}{$\begin{array}{l}\text { Rainy } \\
\text { Dry }\end{array}$} & \multirow{2}{*}{ 04h00-07h00 } & $19.94 b$ & $95.41 \mathrm{a}$ & $68.64 \mathrm{~b}$ \\
\hline & & $22.33 a$ & $96.83 a$ & $71.13 a$ \\
\hline \multirow{2}{*}{$\begin{array}{c}\text { Rainy } \\
\text { Dry }\end{array}$} & \multirow{2}{*}{ 08h00 - 11h:00 } & $22.03 b$ & $90.12 \mathrm{a}$ & $74.89 \mathrm{~b}$ \\
\hline & & $26.13 \mathrm{a}$ & $81.15 b$ & $80.45 a$ \\
\hline \multirow{2}{*}{$\begin{array}{l}\text { Rainy } \\
\text { Dry }\end{array}$} & \multirow{2}{*}{$12 \mathrm{~h} 00-15 \mathrm{~h} 00$} & $23.21 b$ & $85.51 \mathrm{a}$ & $76.49 \mathrm{~b}$ \\
\hline & & $27.74 \mathrm{a}$ & $72.42 b$ & $82.79 a$ \\
\hline \multirow{2}{*}{$\begin{array}{l}\text { Rainy } \\
\text { Dry }\end{array}$} & \multirow{2}{*}{$16 \mathrm{~h} 00-19 \mathrm{~h} 00$} & $21.54 b$ & 90.39 a & $70.05 b$ \\
\hline & & $24.21 \mathrm{a}$ & $84.79 \mathrm{~b}$ & $73.05 a$ \\
\hline \multirow{2}{*}{$\begin{array}{l}\text { Rainy } \\
\text { Dry }\end{array}$} & \multirow{2}{*}{$20 h 00-23 h 00$} & $20.42 b$ & 94.38 a & $68.38 \mathrm{~b}$ \\
\hline & & $22.25 \mathrm{a}$ & $95.71 \mathrm{a}$ & $70.61 \mathrm{a}$ \\
\hline \multicolumn{2}{|c|}{ Mean standard error } & 1.21 & 6.71 & 2.90 \\
\hline
\end{tabular}

Different letters in the column differ from each other by the Tukey test at the level of $5 \%$ probability.

Black globe temperature and humidity index = BTHI.

\section{Table 2}

\section{Effect of the dry and rainy season on the physiological parameters of crossbred dairy cows}

\begin{tabular}{|c|c|c|c|c|}
\hline \multirow{2}{*}{ Variables } & \multicolumn{2}{|c|}{ Season } & \multirow{2}{*}{ SEM } & \multirow{2}{*}{$P$-value } \\
\hline & $\operatorname{Dry}\left(24,05^{\circ} \mathrm{C}\right)$ & Rainy $\left(21,14^{\circ} \mathrm{C}\right)$ & & \\
\hline Rectal temperature $\left({ }^{\circ} \mathrm{C}\right)$ & $38.78 a$ & $38.69 a$ & 0.05 & 0.0620 \\
\hline Surface temperature $\left({ }^{\circ} \mathrm{C}\right)$ & 33.08a & $31.19 b$ & 0.16 & $<.0001$ \\
\hline Respiratory rate (movement min $^{-1}$ ) & $39.53 a$ & $31.34 b$ & 0.98 & $<.0001$ \\
\hline Heart rate (beats min $^{-1}$ ) & $73.13 a$ & $72.33 a$ & 0.89 & 0.3717 \\
\hline
\end{tabular}

Different letters in the column differ from each other by the Tukey test at the level of $5 \%$ probability.

Black globe temperature and humidity index = BTHI.

Even though the animals were kept in environments above the thermal comfort zone, at the hottest times of the day, especially in the dry period of the year, their RT was within the normal range for the species, 37.5 to $39.3^{\circ} \mathrm{C}$ (Rocha, Salles, Moura, \& Araújo, 2012). Lima et al. (2013), in research in the summer period in the state of Pernambuco, Brazil, with crossbred animals kept in a shaded environment and resting state in the afternoon, cited RT values from 38.0 to $39.0^{\circ} \mathrm{C}$ and attributed this increase to the heat necessary to maintain the animals' body temperature due to the greater direct or indirect solar radiation that accumulates during the day. Ávila et al. (2013) worked with Holstein cows in different seasons (rainy and 
spring) and observed an average RT of around $37^{\circ} \mathrm{C}$. Perissinotto et al. (2009) reported that $\mathrm{RT}$ in the range of 38.7 to $39.2^{\circ} \mathrm{C}$ and RR less than or equal to $54 \mathrm{mov} / \mathrm{min}$ indicate a state of thermal comfort.

The thermal gradient between RT and ST was $6.85{ }^{\circ} \mathrm{C}$, which can facilitate heat exchange between the body's core and surface. Lima et al. (2013) cited ST values of $33.4,34.0$ and $34.7^{\circ} \mathrm{C}$ for $1 / 2,5 / 8$ and $3 / 4$ Holstein/ Gir cows, respectively, with lower values for animals with a predominantly zebu genetic composition.

Higher RR values were shown in the dry period, but it remained within the normal range for the species in both seasons (Stober, 1993). This increase may be due to more stressful climatic conditions where, to avoid thermal stress, cattle use the physiological mechanisms of body heat loss, such as increased RR and sweating, to avoid hyperthermia, constituting an efficient means of heat loss by evaporation (Ávila et al., 2013). Lima et al. (2013), evaluating three genetic groups, $1 / 2,5 / 8$ and $3 / 4 \mathrm{HG}$, observed a higher sweating rate and lower values of RF and temperature of the epidermis and surface of the fur in the $1 / 2 \mathrm{HG}$ cows, concluding that the $3 / 4$ and $5 / 8$ HG animals showed greater sensitivity to heat. Ávila et al. (2013), working with Holstein cows in two seasons, observed HR between 60 and 71 beats/min.

There were significant differences $(\mathrm{P}<$ 0.05 ) in milk production and protein percentage betweenseasons, butnosignificant differences ( $P$ > 0.05) in fat, lactose, total solids, SCC and TBC according to the season (Table 3 ).

\section{Table 3}

Effect of the dry and rainy season on the milk production and quality of crossbred dairy cows

\begin{tabular}{lcccc}
\multirow{2}{*}{ Variables } & \multicolumn{2}{c}{ Season } & SEM & P-value \\
\cline { 2 - 3 } & Dry $\left(24.05^{\circ} \mathrm{C}\right)$ & Rainy $\left(21.14^{\circ} \mathrm{C}\right)$ & & 0.0292 \\
Milk production $\left(\mathrm{kg} \mathrm{day}^{-1}\right)$ & $16.51 \mathrm{~b}$ & $19.02 \mathrm{a}$ & 2.57 & 0.5310 \\
Fat (\%) & $4.22 \mathrm{a}$ & $4.08 \mathrm{a}$ & 0.93 & 0.0006 \\
\hline Protein (\%) & $3.75 \mathrm{a}$ & $3.53 \mathrm{~b}$ & 0.29 & 0.9771 \\
Lactose (\%) & $4.44 \mathrm{a}$ & $4.44 \mathrm{a}$ & 0.28 & 0.1421 \\
Total solids (\%) & $12.90 \mathrm{a}$ & $13.24 \mathrm{a}$ & 0.76 & 0.5685 \\
TBC log $\left(\mathrm{n} \mathrm{mL}^{-1}\right)$ & $1.20 \mathrm{a}$ & $1.13 \mathrm{a}$ & 0.35 & 0.0679
\end{tabular}

Standard error means = SEM; Total bacterial count = TBC; Somatic cell count $=$ SCC;

Different letters on the line differ from each other by the Tukey-Kramer test at $5 \%$ probability.

The lower milk production in the dry period may be due to environmental conditions. Higher values of AT and BGTHI cause heat stress in the animals, due to the lower availability and quality of forage which in this period has higher fibre values, as well as by the activation of physiological mechanisms of heat loss, such as increased RR and ST, which expend energy. In both seasons, the milk production can be considered good for crossbred animals in Northeast Brazil. 
Dairy cows kept in thermally comfortable environments feed during the day, improving their production and productivity (Vilela et al., 2013). Among the problems of grazing milk production in tropical regions is the seasonality in forage production: the greater part of dry matter production is concentrated in the rainy season and there is often a lack of food in the dry season, which can lead to a decrease in dry matter intake and consequently a decrease in the availability of nutrients for animal production (Moreira et al., 2015).

The fat levels recorded are above the minimum values (3\%) established by Normative Instruction 76 of Ministério da Agricultura, Pecuária e Abastecimento [MAPA] (2018), and this fat may vary depending on an animal's genetics, lactation period, season and birth order, milk production, nutrition, health, breed and age.

The lower protein content in the rainy season, $4.95 \%$ less than that during the dry season, can be explained by the fact that milk protein varies according to diet, AT, race and lactation period; the values recorded are in accordance with the limits established for chilled raw milk of at least $2.9 \%$ (MAPA, 2018).

The SCC result $(1,000,000$ cells/ $\mathrm{mL}$ ) was normal for the North and Northeast regions of Brazil (MAPA, 2018), and this result is in accordance with B. B. Souza et al. (2010) who found no difference in SCC in holstein/zebu cows with access to shade, when compared to cows without access to shade. Ribeiro, Tamanini, Silva and Beloti (2015), comparing the quality of milk from small and large producers, observed a higher level of contamination in milk produced by small producers, who use less technology in their production. Saravanan, Das and Panneerselvam (2015) studied groups of dairy cows and observed SCC values similar to those in this study. Bernabucci et al. (2015) and Bertocchi et al. (2015) observed higher values for SCC than those of this research in milk of Holstein cows in different seasons.

The TBC results $(120,000$ and 113,000 $\mathrm{UFC} / \mathrm{mL}$ ) for the dry and rainy periods, respectively) are above the standards established by IN 76/2018, which for the Northeast region are $100,000 \mathrm{UFC} / \mathrm{mL}$ for individual milk and 300,000 UFC/mL for aggregated milk. The standard plate count is related to several factors such as the health and hygiene of the cow, and hygiene during the milking process and of the milking equipment, in addition to adequate time and temperature for storage and transportation of milk to beneficiary units.

\section{Conclusion}

The air temperature and BGTHI were higher in the dry period of the year and, based on the BGTHI, the environment conditions in the daytime were above the thermal comfort zone for dairy cattle (dangerous in the rainy season and emergency in the dry season).

The surface temperature and RR, mechanisms used to maintain homeothermy, were higher in the dry season, milk production was higher in the rainy season, and the protein concentration in milk was higher in the dry period of the year. 


\section{References}

Ávila, A. S., Jácome, I. M. T. D., Faccenda, A., Panazzolom, D. M., \& Muller, E. R. (2013). Avaliação e correlação de parâmetros fisiológicos e índices bioclimáticos de vacas holandês em diferentes estações. Revista Eletrônica em Gestão, Educação e Tecnologia Ambiental, 14(14), 2878-2884. doi: 10.5902/22 36117010747

Bernabucci, U., Basiricò, L., Morera, P., Dipasquale, D., Vitali, A., Piccioli Capelli, F., \& Calamari, L. (2015). Effect of summer season on milk protein fractions in holstein cows. Journal Dairy Science, 98(3), 18151827. doi: 10.3168/jds.2014-8788

Bertocchi, L., Vitali, A., Lacetera, N., Nardone, A., Varisco, G., \& Bernabucci, U. (2014). Seasonal variations in the composition of holstein cow's milk and temperature humidity index relationship. Animal, 8(4), 667-674. doi: 10.1017/S175173111400 0032

Instrução Normativa (2000). Ministério da Agricultura. Secretaria Nacional de Agricultura. Instrução Normativa $n^{\circ} 37$, 8 de novembro de 2000. Regulamento Técnico de Produção, Identidade e Qualidade do Leite de Cabra. Diário Oficial da União. Seção 1.

Buffington, D. E., Collazo-Arocho, A., Canton, G. H., \& Pitt, D. (1981). Black Globe-Humidity Index (BGHI) as comfort equation for dairy cows. Transactions of the ASAE, 24(3), 711-714. doi: $10.13031 / 2013.34325$

Diehl, M. S., Olivo, C. J., Agnolin, C. A., Bratz, V. F., Bem, C. M., Aguirre, P.F., \&Serafim, G. (2013). Produtividade de sistemas forrageiros consorciados com leguminosas. Arquivo
Brasileiro de Medicina Veterinária e Zootecnia, 65(5), 1527-1536. doi: 10.1590/ S0102-09352013000500034

Lima, I. A., Azevedo, M., Borges, C. R. A., Ferreira, M. A., Guim, A., \& Almeida, G. L. P. (2013). Thermoregulation of Girolando cows during summertime, in Pernambuco state, Brasil. Acta Scientiarum. Animal Sciences, 35(2), 193-199. doi: 10.4025/ actascianimsci.v35i2.16591

Ministério da Agricultura, Pecuária e Abastecimento (2002). Instrução normativa $N^{\circ} 51$ de 18 de setembro de 2002. Regulamento técnico de produção, identidade e qualidade do leite tipo $A$, do leite tipo $B$, do leite tipo $C$, do leite pasteurizado e do leite cru refrigerado e o regulamento técnico da coleta de leite cru refrigerado e seu transporte a granel. Diário Oficial da União, Brasília, DF, 18 de set. de 2002. Secção 3. Recuperado de http://www.mda.gov.br

Moreira, F. S., Oliveira, M. M. N. F., Villela, S. D. J., Barbosa, F. A., Mourthé, M. H. F., \& Diniz, F. B. (2015). Desempenho produtivo e econômico de três grupos genéticos de bovinos recriados a pasto com suplementação e terminados em confinamento. Arquivo Brasileiro de Medicina Veterinária e Zootecnia, 67(1), 140-148. doi: 10.1590/1678-7250

Pereira, J. C., Cunha, D. N. F. V., Cecon, P. R., \& Faria, E. S. (2008). Desempenho, temperatura retal frequência respiratória de novilhas leiteiras de três grupos genéticos recebendo dietas com diferentes níveis de fibra. Revista Brasileira deZootecnia, 37(2), 328-334. doi: 10.1590/ S1516-35982008000200 020 
Perissinotto, M., Moura, D. J., Cruz, V. F., Souza, S. R. L., Lima, K. A. O., \& Mendes, A. S. (2009). Conforto térmico de bovinos leiteiros confinados em clima subtropical e mediterrâneo pela análise de parâmetros fisiológicos utilizando a teoria dos conjuntos fuzzy. Revista Ciência Rural, 39(5), 1492-1498. doi: 10. 1590/S010384782009005000094

Ramos, A. O., Ferreira, M. A., Santos, D. C., Véras, A. S. C., Conceição, M. G., Silva, E. C., \& Salla, L. E. (2015). Associação de palma forrageira com feno de maniçoba ou silagem de sorgo e duas proporções de concentrado na dieta de vacas em lactação. Arquivo Brasileiro de Medicina Veterinária e Zootecnia, 67(1), 189-197. doi: 10.1590/1678-6537

Ribeiro, J. C., Jr., Tamanini, R., Silva, L., \& Beloti, V. (2015). Qualidade do leite produzido por pequenos e grandes produtores. Semina: Ciências Agrárias, 36(2), 883-888. doi: 10.5433/1679-0359.2015v36n2 p883

Rocha, D. R., Salles, M. G. F., Moura, A. A. A. N., \& Araújo, A. A. (2012). Índices de tolerância ao calor de vacas leiteiras no período chuvoso e seco no Ceará. Revista Acadêmica: Ciências Agrárias e Ambientais, 10(4), 335-343. doi: 10.7213/ academica.7739

Saravanan, R., Das, D. N. S., \& Panneerselvam, S. (2015). Effect of season and parity on somatic cell count across zebu and crossbred cattles population. Indian Journal Animal Research, 49(3), 383-387. doi: 10. 5958/0976-0555.2015.00127.2
Souza, B. B., Silva, I. J. O., Mellace, E. M., Santos, R. F. S., Zotti, C. A., \& Garcia, P. R. (2010). Avaliação do ambiente físico promovido pelo sombreamento sobre o processo termorregulatório em novilhas leiteiras. Agropecuária Científica no Semi-Árido, 6(2), 59-65. doi: 10.30969/acsa.v6i2.69

Souza, R. C., Reis, R. B., Lopez, F. C. F., Mourthe, M. H. F., Lana, A. M. Q., Barbosa, F. A., \& Sousa, B. M. (2015). Efeito da adição de teores crescentes de ureia na cana-deaçúcar em dietas de vacas em lactação sobre a produção e composição do leite e viabilidade econômica. Arquivo Brasileiro de Medicina Veterinária e Zootecnia, 67(2), 564-572. doi: 10.1590/1678-7799

Statistical Analysis System Institute (2001). SAS Language reference. Version 8.2. Cary, NC: SAS Institute Inc.

Stober, M. Identificação, anamnese, regiões básicas da técnica do exame clínico. In M. Rosemberg (Ed.), Exame clínico dos bovinos (3a ed. pp. 411-419). Rio de Janeiro: Guanabara Koogan, 1993.

Vilela, R. A., Leme, T. M. C., Titto, C. G., Fantinato, P., Neto, Pereira, A. M. F., Balieiro, J. C. C., \& Titto, E. A. L. (2013). Respostas fisiológicas e comportamentais de vacas Holandesas mantidas em sistema adiabático evaporativo. Pesquisa Veterinária Brasileira, 33(11), 1379-1384. doi: 10.1 590/S0100-736X 2013001100015 
